\title{
George Bernard Shaw's John Bull's Other Island and Homi K. Bhabha: The Colonizer and the Other in the Third Space
}

\author{
Samira Sasani \\ Assistant Prof. of English Literature, Shiraz University \\ samira.sasani21@yahoo.com
}

\author{
Doi:10.5901/mjss.2015.v6n4s2p324
}

\begin{abstract}
This article aims at a reevaluation of colonial readings of George Bernard Shaw's John Bull's Other Island with regard to its power relationships between the colonizer and the colonized (the Other) and hopes to disavow the traditionally straightforward analysis of the power relations in which the colonizer is considered as the absolute power. This play shows how "colonial mimicry strategy", proposed by Homi K. Bhabha, functions in the hands of both the colonizer and the colonized, through which they mutually exert power and project their desires and fears onto each other and how the identities of the main English figure, Broadbent, and the main Irishmen, Larry and Keegan, are formed in the presence of the Other, by too perfectly or imperfectly (two resistance strategies proposed by Bhabha) imitating the Other.
\end{abstract}

Keywords: George Bernard Shaw; Homi K. Bhabha, colonial mimicry strategy; the Third Space

\section{Introduction}

The literary critics and Shaw's scholars studying George Bernard Shaw's John Bull's Other Island from colonial point of view have applied the straightforward approach to the relationship between the colonizer, Broadbent, and his colonized, the Irish people and none has scrutinized this text from Homi K. Bhabha's point of view in which the identities of the colonizer and the Other are mutually constructed and none has priority over the other in the Third Space Bhabha proposes. The significance of Homi K. Bhabha's post-colonial theories lies in its practicality. What Bhabha proposes practically occurs to the colonizers whom Edward Said has stereotypically portrayed as the absolute power. Huddart claims: "when the relationship between self and other seems to be one of domination, the fact that there is a relationship at all suggest that domination is not total." (2006, p.46) Unlike Said, Bhabha argues that the colonizer is intimidated by the colonized or the colonized has power over the colonizer; in other words the relation between these two parties is mutual and each is dependent on the other. Even their identities are mutually constructed. Thus, the analysis of John Bull's Other Island from Bhabha's point of view is not only a new and unprecedented research but it also reinforces Bhabha's theory highlighting the anxiety of the colonizer and the agency of the colonized which can be considered as the objective of the study.

\section{Theoretical Framework}

Homi K. Bhabha in his influential book, The Location of Culture, emphasizes the mutual power relationship between the colonizer and the colonized. In his view, the power scheme is not a straightforward exertion of power from top to bottom, from the colonizer to the colonized. He deconstructs the binary oppositions, the rigid distinctions between the colonizer and the colonized, the black and white or superior and inferior. In other words, he deconstructs Edwards Said's traditional notion towards the colonizer's straightforward treatment of the colonized as the Other, or the inferior.

Bhabha argues that the colonizer tries to internalize inferiority in the colonized and imposes "mimicry strategy"-he also calls it "sly civility"-onto it; while the colonizer, at the same time, is afraid of the reformed colonized. Bhabha highlights the anxiety of the colonizer and the agency of the colonized. The colonizer wants the colonized almost the same but not quite, Bhabha claims. Bhabha believes that "mimicry is at once resemblance and menace." (1994, p.123) Since becoming quite the same means that the colonizer's authentic identity is paradoxically imitable. Thus, the colonizer is troubled by the Other, the colonized or the colonizer's double.

On the other hand, the colonized exerts power on the colonizer and intimidates it. The colonized resists the colonizer with different resistance strategies. Ball maintains that Bhabha's ideas "show how colonial power relations 
inevitably generate resistance and inhibiting ambivalence as by-products of their discursive and administrative structures of control." (2003, p.37) The colonized deliberately would not imitate the colonizer perfectly or imitates the colonizer too perfectly that it looks fake and artificial. The resistance strategies, as Huddart argues, mean that "mimicry is repetition with difference, and so it is not evidence of the colonized's servitude." (2006, p.39) Huddart argues: "Bhabha's close textual analysis finds the hidden gaps and anxieties present in the colonial situation. These points of textual anxiety mark moments in which the colonizer was less powerful than was apparent, moments when the colonized were able to resist the dominance exercised over them. In short, Bhabha's work emphasizes the active agency of the colonized." (original italics 2006, p.1)

The colonizer tries to make the colonized aware of its difference from the colonized. However, the benefit of this awareness is twofold; both the colonizer and the colonized understand themselves with the help of "Otherness". Iser stipulates: "Otherness turns into a mirror for self-observation, and such a relationship sets the process of selfunderstanding in motion, because the alien that is to be grasped realizes itself to the extent to which one's own dispositions come under scrutiny. The knowledge thus obtained is twofold: by getting to know what is different, one begins to know oneself." (2007, p.36)

Habib also notes that Hegel believes difference to be indispensable to the notion of identity (2008, p.387). Hegel believes that, "identity has its nature beyond itself, in difference . . . . identity and difference are inseparable." (Habib 2008, p.388) Based on Homi K. Bhabah's theory, the identities of the colonizer and the colonized are formed in the Third Space. Bhabha perceives it as: "the encounter of two social groups with different cultural traditions and potentials of power as a special kind of negotiation or translation," which "takes place in a Third Space of enunciation." (Ikas and Wagner 2009, p.2) Based on "The Third Space" theory of Bhabha, "minority groups in the metropoles-marginals within the center-adumbrate a third rhetorical space that disrupts and destabilizes centralized authority." (Huggan 2001, p.21)

\section{Post-colonial Reading of John Bull's Other Island}

John Bull's Other Island is turning round three main characters, two Irish men, Laurence Doyle and Keegan, and an English man, Thomas Broadbent. In this play the colonized and the colonizer are interacting somehow equally and there is no up-to-down gaze from the colonizer to the colonized; in other words, the colonizer and the colonized are interacting in the Third Space proposed by Homi. K. Bhabha. Not only the colonizer exerts power on the colonized but also the colonized intimidates the colonizer with its power. It is not only the colonizer who projects its desires and fears onto the Other, but also the Other does the same. Thus the power relation is not straightforward but complex and mutual. The Other, in John Bull's Other Island, is revealed in two forms of the colonized and the colonizer. In the first part of the play, Laurance Doyle (Larry, the Irish man), is depicted as the Other who is living in England and in the second part of the play, Broadbent is the Other in Roscullen. The play ironically depicts the complex relationship between the colonizer and the colonized.

The play starts while Broadbent and Hodson, his valet, are talking about going to Ireland. The very first stereotypical saying about Irish people, the Others, is stated by the English man, Broadbent, who is expecting to see Tim Haffigan, the Irish man. Broadbent tells Hodson to let Haffigan who "is an Irishman, and not very particular about his appearance" in (Shaw 1964, p.73). England, for Larry and Haffigan, is a land of liberty and independence. They want to be like the English people and to imitate them. On the other hand, Broadbent, the colonizer, valorizes Ireland; entering the Third Space, he tries to become like them; otherwise the Irishmen would be a threat to him and his colonizing purposes.

Intimidating by the colonized's resistance strategy, Broadbent sees no other way than assimilating himself with the Irishmen-entering the Third Space-to be accepted by them and consequently to be allowed to rule them. However, as Homi K. Bhabha maintains, Broadbent, as the Other, becomes almost the same but not quite. In addition, the Irishmen following the "colonial mimicry strategy," also, become almost the same as the English men but not quite the same. As Bhabha theorizes, the "colonial mimicry strategy" is advocated by both parties, the colonizer and the colonized or generally speaking, by the colonizer and the Other, since both parties disavow being quite the same. Colonial mimicry strategy desires: "a reformed recognizable Other, as a subject of difference that is almost the same, but not quite." (original italics, Huddart 2006, p.40)

As Bhabha proposes, the Other's unwillingness to be quite the same as the colonizer roots in its resistance strategy and the colonizer's reluctance settles in its intimidation of creating a double which tacitly encourages the idea of the colonizer's imitable identity which suggests that the colonizer's identity is not authentic and original. Consequently, Larry is almost the same as the English but he is not quite the same. Likewise, Broadbent imitates the Irish people and becomes almost the same as the Irish men but he does not become quite the same; or more accurately they_Larry and 
Broadbent-do not let him to become quite the same. However, in this play, Broadben't reluctance settles in his resistance strategy, since he is not just the colonizer but he is the Other when he goes to Ireland. Therefore, the complex power relation, Bhabha proposes, becomes much more complex, since the Other is transformed throughout Shaw's play. In Bhabha's view, the relation between the colonized and the colonizer is mutual and complex but here, George Bernard Shaw's satirical depiction of this colonial relationship and the way Shaw transforms the Other, makes the power relationship much more complex.

Entering the Third Space, Broadbent tries to get close to the Irishmen's point of view and looks at the world from their equal stance. Ostensibly he is worried about Ireland and wants to improve the land. He tells Tim Haffigan:

I am an Englishman and a Liberal; and now that South Africa has been enslaved and destroyed, there is no country left to me to take an interest in but Ireland. Mind: I dont say that an Englishman has not other duties. He has a duty to Finland and a duty to Macedonia. But what sane man can deny that an Englishman's first duty is his duty to Ireland? Unfortunately, we have politicians here more unscrupulous than Bobrikoff, more bloodthirsty than Abdul the Damned; and it is under their heel that Ireland is now writhing. (Shaw 1964, p.75)

Broadbent claims that he wants to develop an estate there for the Land Development Syndicate, but he wants to handle it as "estates are handled in England" (76). Thus, though he tries to assimilate himself with the Irishmen and becomes the same, he does not want to be quite the same; he has his own English methods. In other words, he resists becoming quite the same as the Irish people. "The inconsistency between Broadbent's behavior and his professed motives means that he is a hypocrite of sorts," McDowell maintains (1967, p.547). For Haffigan, who is Irish, Broadbent is the Other who wants to exploit Ireland:

Broadbent: ... You know the English plan, Mr. Haffigan, dont you?

Tim: Bedad I do, sir. Take all you can out of Ireland and spend it in England: thats it.

Broadbent [not quite liking this]: My plan, sir, will be to take a little money out of England and spend it in Ireland. (Shaw 1964, p.76)

Broadbent, the colonizer, knows that when he goes to Ireland, he is treated as the Other. He tells Haffigan: "when I first arrive in Ireland I shall be hated as an Englishman. As a Protestant, I shall be denounced from every altar. My life may be in danger. Well, I am prepared to face that." (Shaw 1964, p.76) Haffigan, as Shaw ironically depicts, is both the colonizer and the Other, while the Irish people are treated as the Other in England and treat the English peopel as the Other in Ireland. Consequently the colonial relationship Bernard Shaw depicts, many years ago in the nineteenth century, is totally different from the traditionally straightforward depiction of the colonized-colonizer relations. What Shaw has satirically depicted is very much like the mutual relationship Homi K. Bhabha suggests for the colonized and the colonizer, many years later. Satire, Rabb agues: "examine [s] national, historical, or ethnic identity. . . [it] bring[s] objects of fear or danger into our midst by blurring the distinction between the broom and the dirt it sweeps, between us and them, or self and other." (2007, p.582) And this is what Shaw has beautifully portrayed.

What is common between the Irish men and the English men is that both can see themselves in the eyes of the Other. In other words, their identities are formed in the presence of the Other and if there is no difference, there would be no identity. Surely in presence of the Other-the difference-identity is shaped. Thus, it is because of the presence of the Other, Broadbent (the English man), that the Irish people can understand themselves and their identities; likewise Broadbent's identity is shaped by the presence of the Other, the Irish men. Huddart articulates: "colonialism is marked by a complex economy of identity in which colonized and colonizer depend on each other." (2006, p.2) The Other is not something outside or beyond the self, as the traditional Cartesian perspective would have it; rather, it is deeply implicated in and with the self (Türkkan 2011, p.369). Put differently, the colonized is shaped by and also shapes the colonizer; it is gazed at and gazes at the colonizer and that is the mutual complex relationship between the colonizer and the Other which Bhabha suggests. Broadbent sees Haffigan differently; he tells Tim Haffigan:

Broadbent: . . I saw at once that you are a thorough Irishman, with all the faults and all the qualities of your race: rash and improvident but brave and good-natured; not likely to succeed in business on your own account perhaps, but eloquent, humorous, a lover of freedom, and a true follower of that great Englishman Gladstone.

Tim: . . . I mustn't sit here to be praised to me face. But I confess to the goodnature: it's an Irish wakeness. I'd share me last shillin with a friend. (Shaw 1964, p.77)

Tim Haffigan is seen from the colonizer's point of view as the Other, the Irishman with Irish characteristics. On the other hand, Broadbent wants to project his own desires and fears onto the Other, Tim Haffigan. Broadbent wants to make him almost similar to the English man, though not quite the same. He calls him a true follower of Gladstone, the 
Englishman. Tim is just a tool in Broadbent's hands. Broadbent tells Larry: "he's [Tim Haffigan] evidently the very man to take with me to Ireland to break the ice for me. He can gain the confidence of the people there, and make them friendly to me." (Shaw 1964, p.80)

Broadbent mistakenly takes Haffigan as an Irish man. He is actually deceived by a Scotch, Haffigan. Haffigan imitates Irish behavior and deceives the English man. Bernard Shaw's comic approach to colonial discourse is explicitly revealed in Broadbent and Haffigan's relationship. Following his colonial mimicry strategy, Broadbent-the colonizer and the Other-tries to become like the Irish people to colonize them and exploit them while he is unknowingly deceived by the same strategy exerted on him by a Scotch fellow who pretends to be Irish and takes money from Broadbent. This part of the play overtly highlights Huddart's saying about Bhabha's theory of mimicry strategy. Huddart maintains that "this mimicry is also a form of mockery, and Bhabha's post-colonial theory is a comic approach to colonial discourse." (2006, p.39) Broadbent fooled by Haffigan, unbelievably declares: "but he spoke-he behaved just like an Irishman." (Shaw 1964, p.81) Larry Doyle in response to Broadbent very well explains the comic mimicry mechanism, or better to say a comic mimicry business, as Larry calls it:

Doyle: Like an Irishman!! Man alive, dont you know that all this top-o-the-morning and broth-of-a-boy and more-powerto-your-elbow business is got up in England to fool you, like the Albert Hall concerts of Irish music? No Irishman ever talks like that in Ireland, or ever did, or ever will. But when a thoroughly worthless Irishman comes to England, and finds the whole place full of romantic duffers like you, who will let him loaf and drink and sponge and brag as long as he flatters your sense of moral superiority by playing the fool and degrading himself and his country, he soon learns the antics that take you in. (my italics, Shaw 1964, p.81)

Larry, the Irishman, ostensibly pretends that he does not like Ireland and does not want to go back to Ireland with Broadbent. But at times, with some words and actions, he is disturbed and defends Ireland. Very much like Broadbent, Larry, as the Other, employs the colonial mimicry strategy and tries to be almost the same as the English but as Homi K. Bhabha believes, he cannot become quite the same which is rooted in his resistance to servitude. Actually based on Bhabha's theory, the Other resists in two ways while imitating the colonizer: it may imperfectly imitate the colonizer or it may too perfectly imitate that it seems ridiculous. The latter resistance strategy is what Larry does, especially in the first act of the play.

As Bhabha argues, in The Location of Culture, "the discourse of mimicry is constructed around an ambivalence; in order to be effective, mimicry must continually produce its slippage, its excess, its difference" (1994, p.122). Larry goes to extreme and becomes too much English and that is unbelievable for the English man, Broadbent. Seeing Larry's too much resistance not to go back to Ireland and seeing his dissatisfaction of the way the Irish people behave and his too much Englishness, Broadbent warns him that he cannot believe him.

Larry is concealing his Irishness under the veneer of being amusing and agreeable to strangers; however his exaggerated English behavior is an emblem of his resistance to servitude as the Other. Larry with his too much Englishness, on one hand, and on the other hand, by his paradoxically verbal defense of Ireland, at some pivotal moments, plays his role as the ambivalent Other. While Larry is paradoxically condemning the Irish for being too imaginative and condemning himself for his Irish conduct of nagging and being dissatisfied and never quite, Broadbent denies his sayings and reminds him that he is very amusing and agreeable to strangers. This saying outrages Larry who does not want to be quite the same and quite agreeable.

Larry's reaction rises from his resistance strategy, as the Other. He contends: "yes, to strangers. Perhaps if I was a bit stiffer to strangers, and a bit easier at home, like an Englishman, I'd be better company for you." (Shaw 1964, p.83) Broadbent assures him: "we get on well enough," but then he refers to the difference and reminds Larry that he is different and from another race: "of course you have the melancholy of the Keltic race . . . and also its habit of using strong language when theres nothing the matter." (Shaw 1964, p.83) Larry who resists being quite the same as the English men, rejects Broadbent's saying which highlights Larry's difference: "Nothing the matter! When people talk about the Celtic race, I feel as if I could burn down London. That sort of rot does more harm than ten Coercion Acts. Do you suppose a man need be a Celt to feel melancholy in Russcullen? Why, man, Ireland was peopled just as England was; and its breed was crossed by just the same invaders." (Shaw 1964, p.83)

Having defended Ireland, Larry paradoxically condemns the imaginative people of Ireland and derisively condemns his mimicry and his attempt of assimilation. He denounces imagination as the source of all shortcomings and difficulties of Irish people and also their inferiority: "An Irishman's imagination never lets him alone, never convinces him, never satisfies him; but it makes him that he cant face reality nor deal with it nor handle it nor conquer it: he can only sneer at them that do, and [bitterly, at Broadbent] be 'agreeable to strangers,' like good-for-nothing woman on the streets."(Shaw 1964, pp.84-85) 
Larry condemns the Irish people's sense of humor and considers humor and imagination as their shortcomings or the cause of their inferiority. On the other hand, Broadbent takes the previous role of Larry and defends Ireland. Broadbent, as the colonizer, employs the colonial mimicry strategy and ensures Larry that there would be great possibilities for Ireland if the Irish people follow the English guidance and imitate the English policy to govern their country: "We English must place our capacity for government without stint at the service of nations who are less fortunately endowed in that respect; so as to allow them to develop in perfect freedom to the English level of selfgovernment." (Shaw 1964, p.86)

Broadbent wants to make Ireland almost the same as England with his mimicry strategy. When he tries to persuade Larry to go back to Ireland, he tells Larry that Larry is the same as the English people now and thus his family will be delighted to see him: "now that England has made a man of you." (Shaw 1964, p.86) Broadbent wants Larry almost the same but not quite as he later on repeatedly insists that Larry is an Irishman and the things such as South Africa, Free Trade, and Home Rule are not serious to him as an Irishman as they are to an Englishman. As Bhabha maintains: "colonial discourse wants the colonized to be extremely like the colonizer, but by no means identical." (Huddart 2006, p.40) Huddart well represents this ambivalent situation: "the play between equivalence and excess makes the colonized both reassuringly similar and also terrifying." (2006, p.41) And that's why the colonizer does not desire to make the colonized quite the same.

Being in the Third Space, Larry, as the Other, gazes at Broadbent, the colonizer, and criticizes him. In Huddart's sense, "the colonized returns the colonizer's gaze." (2006, p.45) Larry, the Other, intimidates Broadbent since Larry is becoming the same as the colonizer or as Broadbent states, England has been making a man of him. Larry, who is gaining power, criticizes the way the English people, as the Others in his view, shrewdly behave when they go to Ireland and also criticizes the camouflage strategy they use to exploit Ireland. Bhabha employs Lacan's psychoanalytic concept, "camouflage" referring to "blending in with something in the background that none the less is not entirely there itself," (Huddart 2006, p.46) which is very telling of the English man's condition in Ireland. Larry metaphorically calls the Englishman, the caterpillar: "the world is full of fools as a tree is full of leaves. Well, the Englishman does what the caterpillar does. He instinctively makes himself look like a fool, and eats up all the real fools at his ease while his enemies let him alone and laugh at him for being a fool like the rest." (Shaw 1964, p.90)

In the second act of the play, Broadbent, and Hodson, go to Ireland. From now on the roles of these characters are changed. Broadbent and Hodson are considered as the Other by Irish people. The presence of these English people provides a good opportunity for the Irish people to know themselves better. Father Keegan very nicely portrays this very concept of the importance of the presence of the Other for the formation of the identity. At the beginning of the second act, Miss Nora Reilly asks Keegan whether he found Ireland very small and backward when he came back to it from his distant journeys, such as his journeys to Oxford, Rome and other great cities. This conversation at the beginning of the second act is truly suitable for this act in which difference makes identity. Keegan very beautifully stipulates: "When I went to those great cities I saw wonders I had never seen in Ireland. But when I came back to Ireland I found all the wonders there waiting for me. You see they had been there all the time; but my eyes had never been opened to them. I did not know what my own house was like, because I had never been outside it." (Shaw 1964, p.101) With the presence of the Englishmen in Ireland, the Irishmen and the Englishmen can understand their identities better because identity is meaningful in the presence of difference; otherwise there would be no identity.

In the third act of the play, Larry comes to Ireland and joins the Englishmen. Hodson explicitly announces his hatred of the Irish people; he cannot tolerate them. Though, he is the Other in Ireland, and is the valet, he sees the Irish as the Other. Larry, who is in his homeland, treats Broadbent as the Other and also the colonizer; perceiving Broadbent as the colonizer, Larry rebukes Broadbent for his intimidating colonial ideas leading to the exploitation of Ireland: "thats an Englishman all over! make bad laws and give away all the land, and then, when your economic incompetence produces its natural and inevitable results, get virtuously indignant and kill the people that carry out your laws." (Shaw 1964, p.120) Broadbent, as the Other, ties to assimilate himself with the Irishmen and become almost the same and at the same time, he, as the colonizer, does not want to become quite the same as a sign of his resistance to servitude.

Entering the Third Space, Broadbent, as the Other, appreciates Ireland and the Irish people. He appreciates Nora's Irish appearance: "a type rare in England, except perhaps in the best of the aristocracy." (Shaw 1964, p.122) As a colonizer, he projects all his fears and desires onto the Irishmen whom he considers as the Other. He desires to marry Nora, Larry's formerly fiancée, to reach his desires. He is paradoxically the Other and the colonizer in Ireland. His status is very much like the status Bhabha portrays for all the colonizers; in Bhabha's view, they are not the absolute power but they are intimidated by the Other's power; that's why the colonizers desire a reformed recognizable Other and not the Other who is quite the same.

Cornelius, Larry's father, along with some other Irish men suggest Larry become one of the members of the 
Parliament. In contrast to Larry's reluctance, Tom Broadbent is very much interested and some of the Irish people, such as Mathew Haffigan and Larry himself, take Broadbent's side. Father Dempsey and Mathew Haffigan do not believe in the modern Irishman, Larry; Mathew calls Larry a turncoat. Unlike Larry, Broadbent's endeavors for assimilation blossom and he is almost accepted by the Irish people. Broadbent's mottoes of Reformation and Union have been very influential and also very telling of his colonial mimicry strategy a colonizer employs to rule the colonized. Broadbent's Reformation policy of reducing the burden of the rates and taxes very well portrays the colonizer's colonial strategy of keeping the colonized at the level of the reformed but recognizable Other.

Very much like Larry, the Other, who has gone to extreme by too perfectly imitating the English people-which is surely a type of resistance, as Bhabha proposes-Broadbent too enthusiastically advocates Home Rule, even much more than the Irishmen, themselves, which is surely the emblem of his resistance to servitude, to be quite the same as the Irishmen. In response to Cornelius who asks Broadben's opinion about Home Rule, Broadbent, as the stage direction says, rises "so as to address them more imposingly": "I really cannot tell you what I feel about Home Rule without using the language of hyperbole." (Shaw 1964, p.133) Broadbent confesses that his too much enthusiasm and anxiety for the Irish people's future is a trick. He, hugely self-satisfied, addresses Larry: "I think Ive done the trick this time. I just gave them a bit of straight talk; and it went home. They were greatly impressed: everyone of those men believe in me and will vote for me when the question of selecting a candidate comes up. After all, whatever you say, Larry, they like an Englishman. They feel they can trust him, I suppose." (Shaw 1964, p.135)

Unlike Broadbent, Hodson, his valet, expresses his abhorrence very explicitly and unwisely. He cannot tolerate the Irish people and for him, they are the Others. He is ignorant of this fact that he is the Other in their land and that he should employ the colonial strategy his master employs. In contrast with Hodson, Broadbent does not show his hatred overtly. His resistance is operating under the veneer of two types of resistance strategy: by too perfectly imitating the Irish people and devoting his life to the cause of Ireland or by his imperfect imitation. The latter strategy is revealed when he shrewdly addresses Mathew as a "yeomanry" while he pretends that he is not familiar with its Irish connotations; however Larry admonishes him that in Rosscullen a yeoman means a sort of Orange Bashi-Bazouk . Larry mitigates Mathew's anger, informing him that in England they call a freehold farmer a yeoman. Therefore, as the Other in Ireland, Broadbent tries to be almost the same and penetrate in Irish people's hearts but not quite the same.

The forth act of the play starts with the talks about the humorous news of the Haffigan's pig and Broadbent's accident. Broadbent is not still accepted by the Irish people as quite the same. This is the very characteristic of "colonial mimicry strategy"; not only the colonizer but also the colonized or the Other, does not desire to become completely the same. The Irish people still consider Broadbent as the Other and derides him for the funny thing he does. But Broadbent wisely turns the story to another direction - not to get far from them-and declares that he is happy that it has happened since: "it has brought out the kindness and sympathy of the Irish character." (Shaw 1964, p.146) He also tells them that "if it were legally possible I should become a naturalized Irishman." (Shaw 1964, p.147) Nora is deceived by his flattery but Cornelius and Larry know that Broadbent is deceiving them. Cornelius assumes that Broadbent is mocking the Irishmen and Larry, who has always been aware that Broadbent can never become quite the same as the Irishmen, believes that Broadbent, as the Other, does not understand the meaning of the Irish people's derisions but he is wise enough to take the seat of the Parliament while the town is teasing him:

Cornelius: It's all up with his candidature. He'll be laughed out o the town.

Larry: Oh no he wont: he's not an Irishman. He'll never know theyre laughing at him; and while theyre laughing he'll win the seat. (Shaw 1964, p.148)

Very much like Cornelius and Larry, Father Keegan-seeing Braodbent's deceitful attitude towards the Irish people-wisely calls him the hypocrite: "Sir: there was a time, in my ignorant youth, when I should have called you a hypocrite." (Shaw 1964, p.149) Keegan goes further and reveals the identity of the Other, Broadbent, to him. Though Broadbent becomes angry and temporarily loses his confidence, he finds the opportunity of seeing himself differently, from the Other's point of view or generally from a different point of view. Keegan, who is the Other for Broadbent, depicts Broadbent's English identity, as such: "Do not be offended, sir: I know that you are quite sincere. There is a saying in the Scripture which runs-so far as the memory of an oldish man can carry the words - Let not the right side of your brain know what the left side doeth. I learnt at Oxford that this is the secret of the Englishman's strange power of making the best of both worlds." (Shaw 1964, p.150)

What Keegan tells Broadbent metaphorically refers to the way the Englishman "makes the best of both worlds," both the colonizer's world and the Other's. Broadbent well portrays Bhabha's colonizer. He is not the absolute power, when he is the colonizer and not the intimidated, weak, and overwhelmed character when he is the Other. On the other 
hand, Larry and Keegan, the Irishmen, are not in servitude of the colonizer and when in Ireland, they are not completely in power, as Bhabha proposes. Thus, the colonizer is shaped by and shapes the Other.

The Irish identity and the English identity are revealed when each is studied at the presence of the other. Culler believes: "even the idea of personal identity emerges through the discourse of a culture: the "I" is not something given but comes to exist as that which is addressed by and related to others." (qtd. in Ashcroft et al. 2007, p.206) In the presence of the Other, whether the Englishman as the Other or the Irishman, these two identities become meaningful and distinguishable. "In Derrida's words, what we take to be meaning is really only the mental trace left behind by the play of signifiers. And that trace consists of the differences by which we define a word." (qtd in Tyson 2006, p. 253) For Father Keegan, the Irishman, this world is a place of torment and penance; while for Broadbent, the Englishman, the world is quite good and rather a jolly place. From a political point of view, Broadbent is satisfied with this world and sees no evils in the world, "except, of course, natural evils that cannot be remedied by freedom, self-government, and English institutions." (Shaw 1964, p. 152) Broadbent feels quite at home in the world while for Keegan it is not so.

Keegan thanks Broadbent, the Other, for making him think about his own world and his identity: "you have set me thinking. Thank you." (Shaw 1964, p.153) He thanks Broadbent for making him look at his own identity from another point of view, very much like the time when Keegan comments on the Irish and English features and thus makes Broadbent able to see the differences and to understand his own identity deeper through the eyes of the Other. Consequently, Broadbent believes that articulating his own English ideas stimulates Keegan to think about his own Irish identity: "you find that contact with English ideas is stimulating." (Shaw 1964, p.153) Fanon also asserts that:

Man is human only to the extent to which he tries to impose his existence on another man in order to be recognized by him. As long as he has not been effectively recognized by the other, that other will remain the theme of his actions. It is on that other being, on recognition by that other being, that his own human worth and reality depend. It is that other being in whom the meaning of his life is condensed. (2008, pp.168-169)

In Homi K. Bhabha's postcolonial theory the colonial stereotypes, stated in Edward Said's Orientalism, are deconstructed. In the mutual and complex colonizer-colonized relationships proposed by Bhabah, the Other has the opportunity to gaze at the colonizer from the Third Space and consequently the stereotypes formerly describing the colonizers as the source of power are deconstructed. Very much like the Other, the colonizer has the opportunity to look at the colonized or the Other from the equal point of view from the Third Space, thus the formerly traditional stereotypes are deconstructed through the eyes of the colonizer standing at the almost equal level with the Other.

When these different people confront one another, the way they interpret one another's identity deconstructs the formerly traditional stereotypes about the English and the Irish in which the Irish were considered as the people with the strong sense of humor or the English as very serious people with no feelings. Ajtony argues that "on the one hand, the English Broadbent's verbal behavior reveals an Irish identity in so far as his utterances lack humor and irony ..... On the other hand, on surface level Larry Doyle's utterances reveal a fake English stereotype." (2010, p.257) Broadbent also believes that life is too earthly for Larry, the Irishman. Near the end of the play, when Broadbent once again proposes marriage to Nora and cannot recognize her delicately tacit positive response, he reveals to her, her serious Irish identity as Nora also reveals to him his emotional English identity:

\section{Broadbent: . . . You think I have no feeling because I am a plain unemotional Englishman, with no powers of expression. \\ Nora: I dont think you know the sort of man you are at all. Whatever may be the matter with you, it's not want of feeling. Broadbent [hurt and petulant]: It's you who have no feeling. Youre as heartless as Larry. (Shaw 1964, p.161)}

Broadbent, as the colonizer, becomes successful to take Nora from Larry. He not only takes Nora from Larry, but he also takes the seat of Parliament from him. Broadbent is not the absolute power and thus cannot get Ireland from the Irish people without assimilation; in other words, he should pay for it. Huddart maintains that, "colonial authority is menaced by the colonized to the extent that it utterly depends on the colonized for its sense of itself." (2006, p.61) Intimidated by the Irishmen, Broadbent, as the Other, has no other choice than assimilating himself to the codes and norms of Ireland to find way among Irishmen and to be almost accepted by them to get ready for his last stroke which is the exploitation of Ireland. He tells Nora: "I get engaged to the most delightful woman in Ireland; and it turns out that I couldnt have done a smarter stroke of electioneering." (Shaw 1964, p.165) Larry also acknowledges that he loses Nora because he is Irish and Broadbent can take her from him since he is English: "Nora, dear, dont you understand that I'm an Irishman, and he's an Englishman. He wants you; and he grabs you. I want you; and I quarrel with you and have to go on wanting you." (original italics, Shaw 1964, p.166)

Keegan, at the end of the play, objects to Broadbent's deceifful colonial mimicry strategy which leads to his unjust 
success of grabbing the lands and exploiting Ireland; though for Broadbent it is a reasonable success of the efficient man over the inefficient, apart from the political issues of being English or Irish. As a colonizer, he ensures Larry and Keegan that he will try to improve Ireland, to bring money there and to raise wages and to make it like England. Keegan, looking at this matter from the Third Space, derides Broadbent for thinking about making a very modern prison out of Ireland by projecting his desires onto it. Looking at Broadbent and his desires for Ireland from the Third Space, Keegan calls Broadbent an ass: "the ass, sir, is the most efficient of beasts, matter-of-fact, hardy, friendly when you treat him as a fellow-creature, stubborn when you abuse him, ridiculous only in love, which sets him braying, and in politics, which move him to roll about in the public road and raises a dust about nothing." (Shaw 1964, p.172)

Keegan resists Broadbent's colonial mimicry strategy. He does not want to become quite like English people. Broadbent, as the colonizer, wants to make Ireland very much like England, but Keegan contends that Broadbent cannot be successful to make England out of Ireland. Keegan believes that Ireland "produces two kinds of men in strange perfection: saints and traitors," (Shaw 1964, p.172) though in these recent years it is more fitly called the island of the traitors. However he assumes, "the day may come when these islands shall live by the quality of their men rather than by the abundance of their minerals; and then we shall see." (Shaw 1964, p.173) Keegan resorts to his dreams when he sees Ireland in its deplorable condition; however dream, for him is, "a prophecy: every jest is an earnest in the womb of Time." (Shaw 1964, p.176) For Keegan, Ireland is completely different from England. In his dream it is "a country where the State is the Church and the Church the people: three in one and one in three." (Shaw 1964, p.177)

\section{Conclusion}

Looking at Ireland and the Irish people from the Third Space, Keegan sees Ireland still potentially powerful and hopes that one day it gains its lost authority. From that stance, he has the opportunity to gaze at the English people as well. Comparing and contrasting the English people with Irish people, he becomes able to know his own identity and also the identity of his own country much better than before. Actually it is because of these differences that he believes in his own country's potential power more than before. On the other hand, for Broadbent, who is looking at Ireland and England from the Third Space, Ireland is the land of opportunities but he is also intimidated by the Irish power. Therefore, he does not want Ireland to be quite like England with quite the same power and authority. In other words not a quite liberal Ireland, but almost liberal Ireland ruled in the hands of the English, who are, as Broadbent believes, more efficient. Wedeen sarcastically states that in "colonial and modernization discourses people have to move up the evolutionary ladder and become more 'civilized' before they can be free." $(2013$, p.869) And this is exactly the way Broadbent thinks about Ireland.

When Broadbent looks at England from Third Space, England is not that much superior than Ireland. Broadbent likes Ireland and the Irish people, their looks and their accent. Even he likes the stubbornness of Keegan: "if the Church of England contained a few men like Mr. Keegan, I should certainly join it." (Shaw 1964, p.176) However, he does not want to make Ireland quite the same since this action will be a threat for him: it puts the authenticity of his people's identity into question and at the same time, he is consequently encountered by his colonial double who has quite the same power. Thus, the relationship between the colonizer and the colonized or the Other is a mutual relationship in which each is intimidated and also intimidates the other and also is shaped by and shapes the other.

\section{References}

Ajtony, Z. (2010). Humour and Verbal Irony in G. B. Shaw's John Bull's Other Island. Philologica, 2 (2), 246-258.

Ashcroft, B., \& Griffiths G., \& Tiffin H. (2007). Post-Colonial Studies: Key Concepts. New York: Routledge.

Ball, J. C. (2003). Satire and the Postcolonial Novel. New York: Routledge.

Bhabha, H. K. (1994). The Location of Culture. New York: Routledge.

Fanon, F. (2008). Black Skin, White Masks. Charles Lam Markmann (Trans.). London: Pluto Press.

Habib, M. A. R. (2008). A History of Literary Criticism and Theory: Form Plato to Present. Malden, MA: Blackwell.

Huddart, D. (2006). Homi K. Bhabha. New York: Routledge.

Huggan, G. (2001). The Postcolonial Exotic: Marketing the Margins. New York: Routledge.

Ikas, K. \& Wagner G. (2009). Introduction. In K. Ikas and G. Wagner (Eds.), Communication in the Third Space (pp. 1-7). New York: Routledge.

Iser, W. (2007). How to Do to Theory. Singapore: Blackwell.

McDowell, F. P. W. (1967). Politics, Comedy, Character, and Dialectic: The Shavian World of John Bull's Other Island. PMLA 82 (7), $542-553$.

Rabb, M. A. (2007). The Secret Life of Satire. In R. Quintero (Ed.), A Companion to Satire (pp. 568-584). Malden: Blackwell. 
Shaw, G. B. (1964). John Bull's Other Island with How He Lied to Her Husband and Major Barbara. London: Constable and Company Limited.

Türkkan, S. (2011). Other/Alterity. In G. Castl (Ed.), The Encyclopedia of Literary and Cultural Theory Vol.(I) (pp. 369-372). Malden, M.A: Wiley-Blackwell.

Tyson, L. (2006). Critical Theory Today: A User-Friendly Guide. New York: Routledge.

Wedeen, L. (2013). Ideology and Humor in Dark Times: Notes from Syria. Critical Inquiry 39 (4), 841-873. 